\title{
Horizontal transmission of hepatitis B virus amongst British 2nd World War soldiers in South-East Asia
}

\author{
Geoffrey V. Gill, ${ }^{1,3}$ Dion R. Bell' and Elise M. Vandervelde ${ }^{2}$
}

${ }^{1}$ Department of Tropical Medicine and Infectious Diseases, Liverpool School of Tropical Medicine, Pembroke Place, Liverpool L3 5QA, ${ }^{2}$ Virus Reference Laboratory, Central Public Health Laboratory, Colindale Avenue, London NW9 5 HT and ${ }^{3}$ Department of Medicine, Arrowe Park Hospital, Wirral, Merseyside L49 SPE, UK.

\begin{abstract}
Summary: Infection with hepatitis B virus (HBV) is much more common in tropical than in temperate countries. Visitors to the tropics are thus at risk from $\mathrm{HBV}$, though the degree of risk, and the routes of infection involved are uncertain. We report serological markers of $\mathrm{HBV}$ in two groups of 2 nd World War soldiers, who served in the Thai/Burma jungles. The groups comprised 100 ex-prisoners of the Japanese (POW), and 100 Burma Campaign Veterans (BCV). Surface antigen to HBV (HbsAg) was positive in $0 \%$ of POW and $2 \%$ of BCV ( $P=$ not significant). Surface antibody (anti-HBs) and core antibody (anti-HBc) were both positive in $40 \% \mathrm{POW}$ and $13 \% \mathrm{BCV}(P<0.001)$. Quoted UK prevalence rates for these markers are $0.1 \%$ for HBsAg, $1.5 \%$ for anti-HBs and $0.7 \%$ for anti-HBc. Both groups thus show very high rates of past $\mathrm{HBV}$ infection. For the POW there were many possible reasons, including contaminated surgical instruments and needles, blood transfusions, and multiple beatings with common weapons. None of these factors operated significantly for BCV. Malarial transmission was, however, intense in both groups, though more so in POW. The data thus again raise the possibility of horizontal transmission of $\mathrm{HBV}$ by biting insects in tropical countries.
\end{abstract}

\section{Introduction}

Hepatitis B virus (HBV) infection is common in tropical countries. Thus, the carrier rate of HBV surface antigen (HBsAg) in such countries may be $5 \%$ or more, ${ }^{1}$ compared with rates of $0.1 \%$ in the United Kingdom. ' $V$ ertical' transmission from mother to child is important in tropical countries, but 'horizontal' infection also occurs, ${ }^{3}$ and visitors to such countries are at increased risk of HBV infection. ${ }^{4}$ Sexual and parenteral spread are well described routes of infection, and insect-borne transmission (especially by mosquitoes) is a further possibility. ${ }^{5}$

Former 2nd World War prisoners of the Japanese suffered severe hardships and illness in the jungle camps of South-East Asia. The survivors have persisting health problems, including infections with the nematode worm Strongyloides stercoralis, ${ }^{6}$ and increased rates of HBsAg carriage. ${ }^{7}$ In this study we have compared serological evidence of past $\mathrm{HBV}$ infection in British former prisoners of the Japanese (POW), with that in Burma Campaign Veterans $(\mathrm{BCV})$. The latter group fought in the same geographical location at a similar time,

Correspondence: G.V. Gill M.Sc., M.D., F.R.C.P., D.T.M. \& H., Liverpool School of Tropical Medicine, Pembroke Place, Liverpool L3 5QA, UK.

Accepted: 5 September 1990 but they were not imprisoned and did not suffer such intense hardships and disease.

\section{Patients and methods}

Both the POW and BCV hold annual reunions at resorts on the Yorkshire coast of England. We visited these reunions, and took serum samples from 100 randomly selected volunteers in each of the two groups. Samples were stored deep frozen, and analysed in batch for $\mathrm{HBsAg}$, hepatitis B surface antibody (anti-HBs), and core antibody (anti- $\mathrm{HBc}$ ), all by radioimmunoassay. In addition, serum alpha-fetoprotein (alpha-FP) was measured.

\section{Results}

These are summarized in Table $I$, and show that, overall, $40 \%$ of POW had positive HBV markers, compared with $13 \%$ BCV (general population rates being about $2 \%$ ). The markers of infection were mainly anti-HBs and anti-HBc.

Serum alpha-FP levels were $4.7 \pm 3.2 \mu \mathrm{g} / 1$ in POW, and $5.6 \pm 2.7 \mu \mathrm{g} / \mathrm{l}$ in BCV (means \pm 1 standard deviation, reference range up to $10 \mu \mathrm{g} / \mathrm{l}$, no statistical difference by $t$-testing). 
Table I Hepatitis B virus markers in ex-prisoners (POW) and Burma Campaign Veterans (BCV) of the 2nd World War

\begin{tabular}{lccc}
\hline HBV marker & $\begin{array}{c}P O W \\
(n=100)\end{array}$ & $\begin{array}{c}B C V \\
(n=100)\end{array}$ & UK rates \\
\hline $\begin{array}{l}\text { 1. Surface antigen } \\
\text { (HBsAg) }\end{array}$ & $0 \%$ & $2 \%$ & $0.1 \%^{2}$ \\
$\begin{array}{l}\text { 2. Surface antibody } \\
\text { (anti-HBs) }\end{array}$ & $40 \%$ & $13 \%$ & $1.5 \%^{8}$ \\
$\begin{array}{l}\text { 3. Core antibody } \\
\text { (anti-HBc) }\end{array}$ & $40 \%$ & $13 \%$ & $0.7 \%^{9}$ \\
Total markers & $40 \%$ & $13 \%$ & about $2 \%$ \\
\hline
\end{tabular}

Notes: 1 . As $n=100$ for both groups, numbers positive are the same as percentages.

2. UK rates are from previously reported blood donor surveys (see text). HBV antibody rates vary a little in other surveys, e.g. $1.6 \%$ for anti-HBs and $1.3 \%$ for anti-HBc. $^{10}$

3. Comparing HBV marker rates for POW and BCV by $t$ testing, there was no significant differences for $\mathrm{HBsAg}$; but for anti-HBs, anti-HBc, and total HBV markers, POW levels were greater than BCV levels highly significantly $(P<0.001)$.

\section{Discussion}

Our results show very high levels of serum markers of past HBV infection in POW; and also lesser though still substantial - rates in BCV $(40 \%$ and $13 \%$ respectively). Exact comparative rates for the 'normal' UK population are difficult to find. The rates quoted in Table $\mathrm{I}^{2,8-10}$ relate to large blood donor studies. Results from these studies are affected, for example, by age, ethnic origin, and the inclusion or otherwise of high-risk groups such as homosexuals. ${ }^{10}$ When those with a history of jaundice, and homosexuals, are excluded, rates of about $0.1 \%$ are found for $\mathrm{HBsAg}, 1-2 \%$ for anti-HBs, and around $1 \%$ for anti-HBc (see Table I). ${ }^{2,8-10}$ Whatever are the exact figures for HBV markers in the UK, the rates we have found for POW $(40 \%)$ and BCV (13\%) are obviously grossly in excess, with the POW having significantly higher rates than the BCV $(P<0.001)$.

Since the war, many 2nd World War soldiers have died, and we have thus studied a group of survivors. It seems, therefore, probable that HBV positivity would have been considerably higher in the years immediately after the war, and that HBV infection may have contributed to some premature deaths. Indeed, it is known that American ex-POW of the Far East had significant excess mortality from cirrhosis in the late 1940s and early 1950s. ${ }^{11}$ The alpha-FP levels in our subjects were all normal, but HBV-associated hepatoma and/or cirrhosis would probably have arisen earlier.
The carrier rate of HBsAg in North Thailand is $4.6 \%,{ }^{1}$ and our ex-servicemen presumably acquired HBV by local horizontal transmission. For the POW there were many potential infective routes. Medical and surgical treatment in the jungle camps were primitive, with communal and poorly sterilized needles and instruments, curretting of tropical ulcers with sharpened spoons, and blood transfusions from other prisoners. The Japanese guards often beat several men with the same bamboo cane, drawing blood on each occasion. 'Glass rodding' occurred on occasions - this was a bizarre Japanese system of amoebiasis screening which involved taking rectal smears from consecutive POW with the same glass rod. 'Orienteers' or 'track-finders' hepatitis relates to hepatitis transmission from cuts and grazes incurred when people move through densely wooded country, ${ }^{12}$ though it is now generally thought that transfer of virus during the original outbreak was mainly related to communal bathing after the event. ${ }^{13}$ Homosexuality (and indeed any sexual activity) was extremely uncommon.

A final possible mode of $\mathrm{HBV}$ transmission could be by insects. It has been known for some time that the virus may be found in mosquitoes in malarial areas. ${ }^{14}$ This is also true for bed bugs, and in these insects, mechanical transmission of HBV to experimental animals has been demonstrated. ${ }^{5}$ Malarial transmission was intense amongst POW in South-East Asia, and the bed bug was a constant nocturnal companion.

The Burma Veterans were much less exposed to most of these modes of transmission. There was no significant sexual activity, no beatings, and no 'glass roddings'. Primitive surgery and blood transfusions were not needed. The 'orienteers' route of transmission would seem unlikely in either group. The BCV were, however, exposed to insects as were the POW, though malarial transmission was less intense, and the BCV were generally in the jungle areas for shorter periods than the POW. This could thus explain the finding of high HBV rates in both groups, but a substantial excess in POW.

The data presented here thus provide interesting information on the intensity and persistence of HBV infection amongst unprotected expatriates exposed to tropical environments. Finally, the possibility of a role for biting insects in transmitting HBV in warm climates still cannot be excluded.

\section{Acknowledgements}

We are grateful to the ex-prisoners of the Far East and Burma Campaign Veterans, who kindly took part in this study. The helpful advice of Dr Philip Mortimer and Dr John Barbara is also gratefully acknowledged and also the technical help of Mr Brian Megson. 


\section{References}

1. Snitbahn, R., Scott, R.M., Bancroft, W.H., Top, F.H. \& Chiewsilp, D. Subtypes of hepatitis B surface antigen in South-East Asia. J Infect Dis 1975, 131: 708-711.

2. Wallace, J., Milne, G.R. \& Barr, A. Total screening of blood donations for Australia (hepatitis associated) antigen and its antibody. Br Med J 1972, 1: 663-664.

3. Davis, L.G., Weber, D.J. \& Lemon, S.M. Horizontal transmission of hepatitis B virus. Lancet 1989, i: 889-893.

4. Dawson, D.G., Spirey, G.B., Korelitz, J.J. \& Schmidt, R.T. Hepatitis B: risk to expatriates in South East Asia. Br Med J 1987, 294: 547.

5. Leading Article. Bed bugs, insects and hepatitis B. Br Med J 1979, 2: 752 .

6. Gill, G.V. \& Bell, D.R. Strongyloides stercoralis infection in former Far East prisoners of war. Br Med J 1979, 2: 572-574.

7. Gill, G.V., Selkon, J.H., Mortimer, P.P. \& Vandervelde, E.M. Hepatitis B infection in former prisoners of the Japanese. Lancet 1980, ii: 918 .

8. Tedder, R.S., Cameron, C.H., Barbara, J.A.J. \& Howell, D. Viral hepatitis markers in blood donors with history of jaundice. Lancet 1980, i: 595-596.
9. Cohen, B.J. \& Cossart, Y.E. Application of a screening test for antibody to hepatitis B core antigen. J Clin Pathol 1977, 30: 709-713.

10. Tedder, R.S., Cameron, C.H., Wilson-Croome, R., Howell, D.R., Colgrove, A. \& Barbara, J.A.J. Contrasting patterns and frequency of antibodies to the surface, core and $e$ antigens of hepatitis $B$ virus in blood donors and in homosexual patients. J Med Virol 1980, 6: 323-332.

11. Nefzger, M.D. Follow-up studies of World War II and Korean War prisoners. I: Study plan and mortality findings. Am J Epidemiol 1970, 91: 123-138.

12. Gille, G., Ringertz, O. \& Zetterberg, B. Serum hepatitis among Swedish track finders. II. A clinical study. Acta Med Scand 1967, 182: 129-135.

13. Ringertz, O.\& Zetterberg, B. Serum hepatitis among Swedish track finders. An epidemiologic study. $N$ Engl J Med 1967, 276: $540-546$.

14. Brotman B., Prince, A.M. \& Godfrey, H.R. Role of arthropods in transmission of hepatitis B virus in the tropics. Lancet 1973, i: 1305-1308. 